\title{
The use of rocuronium in giant Amazon turtle Podocnemis expansa (Schweigger, 1812) (Testudines, Podocnemididae) ${ }^{1}$
}

\author{
Uso do rocurônio em tartaruga da Amazônia Podocnemis expansa (Schweigger, 1812) \\ (Testudines, Podocnemididae)
}

\author{
Andréa Cristina Scarpa Bosso ${ }^{\mathrm{I}}$, André Luiz Quagliatto Santos ${ }^{\mathrm{II}}$, Fernando Moraes Machado Brito ${ }^{\mathrm{III}}$, José Roberto Ferreira \\ Alves Júnior ${ }^{\mathrm{IV}}$, Ednaldo Carvalho Guimarães ${ }^{\mathrm{V}}$ \\ I Master, Veterinary Sciences, UFU, Scholarship National Council for Scientific and Technological Development (CNPq), Brazil.
II PhD, Full Professor, Animal Anatomy, LAPAS - UFU, Minas Gerais, Brazil.
III Master, Veterinary Sciences, UFU, Environment Specialist, Federal University of Rio de Janeiro, Brazil.
IV Master, Veterinary Sciences, UFU, Minas Gerais, Brazil.
${ }^{\text {v }} \mathrm{PhD}$, Associate Professor, Biostatistics and Techniques in Experimental Animals, Faculty of Mathematics, UFU, Minas Gerais, Brazil.
}

\begin{abstract}
Purpose: To determine whether rocuronium would provide safe, short-term immobilization in Podocnemis expansa. Methods: Twenty P. expansa, weighing on average $1.59 \pm 0.28 \mathrm{~kg}$, were subjected to two protocols: $\mathrm{G} 10.25 \mathrm{mg} / \mathrm{kg} \mathrm{IM}$ of rocuronium and $0.07 \mathrm{mg} / \mathrm{kg} \mathrm{IM}$ of neostigmine, while G2 received $0.50 \mathrm{mg} / \mathrm{kg}$ IM of rocuronium and $0.07 \mathrm{mg} / \mathrm{kg}$ IM of neostigmine. The drugs were applied, respectively, in the left and right thoracic members. Assessments were made of the anesthetic parameters of respiratory frequency, heartbeat, righting reflex, cloacal relaxation, palpebral and pupilar reflexes, easy handling, muscle relaxation, locomotion, response to pain stimuli in the right thoracic members, pelvic members and tail, ambient humidity and temperature. Results: They were not found statistical differences between the dosages for the majority of the assessments. G1 was as efficient as G2. A consistent neuromuscular blockade effect was recorded $12 \pm 4.21$ minutes in G1 and G2. All the animals were recovered in 150 minutes. Conclusions: Administration of rocuronium at dose of 0.25 to $0.5 \mathrm{mg} / \mathrm{kg} \mathrm{IM}$ is a safe and effective adjunct to clinical proceedings or pre-anesthetics in $P$. expansa. Because rocuronium does not provide any analgesic or sedative effects, the duration of neuromuscular blockade without anesthesia should be minimized to avoid undue stress.
\end{abstract}

Key words: Anesthetics. Neuromuscular Blocking Agents. Reptiles.

\section{RESUMO}

Objetivo: Determinar se o rocurônio promove imobilização segura e de curta duração em Podocnemis expansa. Métodos: Vinte $P$. expansa com média de peso $1,59 \pm 0,28 \mathrm{~kg}$, foram submetidas a dois protocolos: G1 recebeu rocurônio $0,25 \mathrm{mg} / \mathrm{kg} \mathrm{IM}$ e neostigmina $0,07 \mathrm{mg} / \mathrm{kg}$ IM enquanto G2 rocurônio $0,50 \mathrm{mg} / \mathrm{kg}$ IM e neostigmina $0,07 \mathrm{mg} / \mathrm{kg} \mathrm{IM}$, aplicados no membro torácico esquerdo e direito, respectivamente. Observaram-se os parâmetros anestésicos: freqüência respiratória e cardíaca, reflexo de endireitamento, relaxamento do esfíncter da cloaca, reflexo palpebral e pupilar, facilidade de manipulação, relaxamento muscular, locomoção, resposta aos estímulos dolorosos no membro torácico direito, nos membros pelvinos e na cauda, temperatura e umidade ambiental. Resultados: Não foram encontradas diferenças estatísticas entre as doses para a maioria dos parâmetros e o G1 foi tão eficiente quanto o G2. Um bloqueio neuromuscular consistente foi observado aos $12 \pm 4,21$ minutos tanto no G1 como no G2. A recuperação de todos os animais ocorreu em até 150 minutos. Conclusões: Administração de rocurônio nas doses 0,25 e 0,50 mg/kg IM é segura e efetiva para os procedimentos clínicos ou pré-anestésicos em $P$. expansa. Como o rocurônio não produz efeitos sedativos ou analgésicos, a duração do bloqueio neuromuscular sem anestesia deverá ser minimizado para evitar estresse.

Descritores: Anestésicos. Bloqueadores Neuromusculares. Répteis.

${ }^{1}$ Research performed at Wild Animals Research Laboratory, Federal University of Uberlandia (LAPAS - UFU), Minas Gerais, Brazil.

\section{Introduction}

Amazon river turtle is distributed in the Amazon river basin, which encompasses equatorial forest and savannah ecosystems in the northern and mid-western regions of Brazil ${ }^{13}$. CITES $^{\mathrm{a}}$ and IUCN ${ }^{\mathrm{b}}$ today classify this animal as conservation dependent to not being under threat of extinction. In the eminence

\footnotetext{
${ }^{a}$ Convenrion on International Trade in Endangered Species of Wild Fauna and Flora

${ }^{b}$ International Union for Conservation of Natures and Natural Resources
} 
of the illegal threat with the capture of the animals in its habitats, there were published the IBAMAc Order no. 142/92, to govern the commercial breeding and legal consumption of terrapins provided from captivity.

Pharmacological restraint of turtles for routine physical examination and diagnostic or therapeutic procedures is often required in zoological institutions, exotic animal breeding and wildlife and exotic animal practices. However, the anesthetic induction in this species may be complicated by its anatomical and physiological characteristics, including its ability to hold breath for long periods, hiding the head under the carapace, difficulty of venous access or slow or irregular absorption and metabolism of anesthetic injection ${ }^{4}$.

Several authors ${ }^{2,12}$ assert that rocuronium (ORG 9426) is an adepolarizing neuromuscular blocker (NMB) of the steroid group, with $1 / 5$ of the power of its analogue, vecuronium. Its marked characteristic is the faster onset of its action in mammals than that provided by other commercially available relaxants, without causing the release of histamine or any major cardiovascular effect. Blockage reversal, or decurarization, consists of the phase in which the intention is to increase the concentration of acetylcholine $(\mathrm{ACh})$ in the motor endplate by administering an anticholinesterase inhibitor such as neostigmine.

The purpose of this paper is to describe the results and side effects of pharmacological containment with neuromuscular rocuronium in doses of $0.25 \mathrm{mg} / \mathrm{kg} \mathrm{IM}$ and $0.50 \mathrm{mg} / \mathrm{kg}$ IM in P. expansa.

\section{Methods}

Under permit no. 28771 from IBAMA-RAN ${ }^{\mathrm{d}}, 20$ healthy specimens of $P$. expansa (12 males and 8 females), approximately three years old, were supplied by the commercial breeder Fazenda Moenda da Serra, in the municipality of Araguapaz, state of Goiás, Brazil (1504'18'S and 50²5'2.4”W - 340 m altitude), and kept in fattening tanks. After they were captured using nets, the animals were taken to the study environment, weighed and identified individually.

During the experiment, the temperature was checked with a maximum/minimum thermometer and the humidity with a hygrometer. The specimens were divided into two groups, which were given $0.25 \mathrm{mg} / \mathrm{kg} \mathrm{IM}$ and $0.07 \mathrm{mg} / \mathrm{kg}$ IM neostigmine (G1), and $0.50 \mathrm{mg} / \mathrm{kg}$ IM rocuronium and $0.07 \mathrm{mg} / \mathrm{kg}$ IM neostigmine (G2) sequentially, as suggested by Kauffmann? ${ }^{7}$. After antisepsis, rocuronium was administered in the muscle of the left thoracic member, and five min after the effect of muscle relaxation 3 and handling 3 took hold, neostigmine was applied in the muscle of the right thoracic member, using $25 \times 0.70 \mathrm{~mm}$ hypodermic needles with syringes. After $0,5,10,20,30,45,60,90,120,150$ and 180 min, the following parameters were checked and recorded on individual charts. Time 0 (zero) was the moment when rocuronium was adminstred. Subjective scores of one (1) for minimal effects, two (2) for intermediary effects, and three (3) for maximum effect were used for the first three parameters described below. For the pain sensitivity tests, pulling back of the member in response to pinching was given a score of zero $(0)$ and its absence, a score of one (1).

\section{The following parameters were evaluated:}

I - Respiratory rate: the count of respiratory movements occurring in one minute (mpm), waiting for at most five min to begin the count of the first respiratory movement, based on the skin's pumping movements at the base of the members.

II - Heartbeat: measurement of the number of heartbeats per minute (bpm), using a vascular Doppler.

III - Righting reflex: (0) presence of the attempt of the animal in turn itself to the dorsal decubitus (1) absence of that attempt;

IV - Relaxation of the cloacal sphincter - (0) contraction of the cloacal sphincter, and (1) relaxed sphincter.

V-Palpebral reflex: (0) the animal closes its eyelids when it is touched lightly at the edge of an eye, and (1) absence of this reflex.

VI - Pupillary reflex: $(0)$ contraction of the pupil when light is directed at the eye, and (1) absence of this reflex.

VII - Handling: (1) difficulty in flexing and extending the head, members and tail and in opening the animal's mouth manually, (2) intermediary situation, and (3) no resistance to manipulation of the head, members and tail, or to opening the animal's mouth.

VIII - Muscle relaxation: (1) the animals kept its head up or retracted, (2) an intermediary situation, and (3) the head, members and tail remained suspended and relaxed.

IX - Locomotion: (1) animal with normal ability to move, (2) difficulty to move, and (3) absence of movement.

$\mathrm{X}$ - Sensibility to pain in the right thoracic member: applying a pair of $16 \mathrm{~cm}$ curved hemostatic Kelly pincers at the second lock on the phalanges of the forepaw, one waits for the response elicited by the removal of the pain stimulus, which is classified as zero (0) or absence of the response, one (1).

XI - Sensibility to pain in the pelvic members: the procedure is similar to that of item 4 , but the pincers are applied to the phalanges of the hindpaw

XII - Sensibility to pain in the tail: the procedure is similar to that of item 4 , but the pincers are applied to the skin of the tail.

The neuromuscular blocking effect was considered optimal when muscle relaxation 3 and handling 3 were achieved, with loss of palpebral reflex.

The check for the presence or absence of significant differences in the recorded values, Student's $t$-test was applied for the normal distributions, as well as the Mann-Whitney nonparametric $U$ test and the binomial test of two proportions, with a 0.05 level of significance.

\section{Results}

Prepubescent turtles without significant differences in mass were used, having a mean weight of $1.59 \pm 0.28 \mathrm{~kg}$. The ambient temperature and humidity also did not vary, remaining at $33.73 \pm 1.88^{\circ} \mathrm{C}$, while the relative air humidity was $23.97 \pm 2.12 \%$.

All the animals survived the experiment and presented evident neuromuscular blockage. No signs of recovery were detected in the five min preceding the application of neostigmine,

\footnotetext{
c Instituto Brasileiro do Meio Ambiente e dos Recursos Naturais Renováveis (Brazilian Institute of Environment and Renewable Natural Resources)
}

${ }^{\mathrm{d}}$ Centro de Conservação e Manejo de Répteis e Anfíbios (Center for Reptile and Amphibian Conservation and Handling) 
when effect of the rocuronium was optimal at $12 \pm 4.21 \mathrm{~min}$ in both G1 and G2. All the turtles lost their straightening reaction, palpebral reflex, showed cloacal relaxation, became easy to handle and were inactive (loss of spontaneous locomotion and relaxed muscles) and, at some point, did not respond to painful stimulation of the members.

The respiratory movements decreased in intensity as the effect of the NMB became more consistent. The respiratory rate varied from zero to 29 mpm, with a mean rate at time zero of 9 $\pm 7 \mathrm{mpm}$ in $\mathrm{G} 1$ and $14.80 \pm 11.97 \mathrm{mpm}$ in $\mathrm{G} 2$, and a total average of $3.49 \pm 3.51$ $\mathrm{mpm}$ in $\mathrm{G} 1$ and $7.72 \pm 8.06 \mathrm{mpm}$ in $\mathrm{G} 2$. The respiratory movements began with strong standard pumping movements observed on the skin associated with slight movements of the members, becoming more superficial and faster, up to apnea, which was observed at $13 \pm 6$ min in G1 and at $12 \pm 7 \mathrm{~min}$ in G2. Two animals in G1 and three in G2 did not reach apnea, but presented from one to three superficial respiratory movements in one minute at every five. $\mathrm{P}>0.05$ occurred at time zero and at 60,90 and $120 \mathrm{~min}$.

The recorded heart rate was $38.20 \pm 8.94 \mathrm{bpm}$ in $\mathrm{G} 1$ and $37.31 \pm 9.78$ bpm in G2. Three animals, two from G2 and one from $\mathrm{G1}$, which coincidentally received neostigmine at $15 \mathrm{~min}$, displayed bradycardia: one turtle from G2 and the one from G1 started, respectively, from $49 \mathrm{bpm}$ and from $50 \mathrm{bpm}$ at time zero to $14 \mathrm{bpm}$ at $45 \mathrm{~min}$ and to $8 \mathrm{bpm}$ at $60 \mathrm{~min}$. When they were given a dose of $0.02 \mathrm{mg} / \mathrm{kg}$ IM atropine, they returned to $30 \mathrm{bpm}$ at $120 \mathrm{~min}$ and to $42 \mathrm{bpm}$ at $180 \mathrm{~min}$. The heart rate of the first turtle of G2 started from $36 \mathrm{bpm}$ at time zero to $14 \mathrm{bpm}$ at 20 min, but recovered spontaneously, without medication, to $46 \mathrm{bpm}$ at $150 \mathrm{~min}$

G1 presented loss of straightening reaction at $6 \pm 2.10$ $\min$ and $\mathrm{G} 2$ at $8 \pm 4.83 \mathrm{~min}$, recovering at $3.50 \pm 36.36 \mathrm{~min}$ in $\mathrm{G} 1$ and at $52.50 \pm 7.90 \mathrm{~min}$ in G2. Relaxation of the cloacal sphincter occurred at $7 \pm 3.66 \mathrm{~min}$ in G1 and at $10 \pm 4.08 \mathrm{~min}$ in G2, while recontraction was recorded at $36.50 \pm 11.79 \mathrm{~min}$ in $\mathrm{G} 1$ and at 48 $\pm 11.82 \mathrm{~min}$ in G2. These parameters did not show significant differences inside and between the two groups. All the animals in G1 showed early loss of palpebral reflex, at $5.50 \pm 1.58 \mathrm{~min}$, in contrast to the $9.5 \pm 5.98 \mathrm{~min}$ in G2, recovering at $30 \pm 9.12 \mathrm{~min}$ in $\mathrm{G} 1$ and at $46.50 \pm 11.06 \mathrm{~min}$ in $\mathrm{G} 2 . \mathrm{p}>0.05$ occurred at $5 \mathrm{~min}$, when G1 lost this reflex, and at $30 \mathrm{~min}$, when G1 had already recovered and G2 had not, as indicated in Figure 1.

Loss of palpebral reflex was recorded in only one specimen in G1, at 10 to $30 \mathrm{~min}$, and in eight animals from G2, at $21.87 \pm 9.97 \mathrm{~min}$, with recovery recorded at $52.50 \pm 17.92 \mathrm{~min}$, presenting a statistically significant difference at 20 and $30 \mathrm{~min}$.
A score of 3 was obtained for the handling parameter at $12 \pm 4.21 \mathrm{~min}$ with doses of $0.25 \mathrm{mg} / \mathrm{kg} \mathrm{IM}$ and $0.50 \mathrm{mg} / \mathrm{kg} \mathrm{IM}$ rocuronium, showing consistent neuromuscular blockage that allowed for physical examinations, collection of material, painless procedures, and probably the beginning of anesthesia using inhalation agents supported by oxygen therapy. Statistically significant differences were found between the groups at 20, 30 and $45 \mathrm{~min}$, as depicted in Figure 2. Most of the animals had recovered by $150 \mathrm{~min}$, with mean times of $108 \pm 25.29 \mathrm{~min}$ in $\mathrm{G} 2$ and $114 \pm 27.56 \mathrm{~min}$ in G1, despite the lower dosage administered to the latter group. The recovery time in G1 was high due to the specimen that presented bradycardia (which recovered at $180 \mathrm{~min}$ ).

None of the measurements showed significant differences between and inside the groups with respect to the parameters of muscle relaxation and locomotion.

The inability to respond to painful stimulus proceeded in the cranio-caudal direction and was observed in both groups at some moment, up to $20 \mathrm{~min}$, showing $\mathrm{p}>0.05$ at $20 \mathrm{~min}$ in the right thoracic member and at $30 \mathrm{~min}$ in the pelvic members and tail, suggesting more intense effects related to the increase in dosage. In $\mathrm{G} 1$, loss of the response to painful stimulus in the thoracic member occurred at $11.50 \pm 6.25 \mathrm{~min}$ and in $\mathrm{G} 2$ at $12 \pm 4.21 \mathrm{~min}$; 
loss of painful stimulus in the pelvic members occurred at $12 \pm$ $5.86 \mathrm{~min}$ in $\mathrm{G} 1$ and at $12.50 \pm 7.16 \mathrm{~min}$ in $\mathrm{G} 2$; and loss of painful stimulus in the tail was recorded at $13.50 \pm 5.79 \mathrm{~min}$ in $\mathrm{G} 1$ and at $12.50 \pm 7.16 \mathrm{~min}$ in G2. Recovery of this response in the thoracic member occurred at $26 \pm 5.16 \mathrm{~min}$ in $\mathrm{G} 1$ and at $25 \pm 5.16 \mathrm{~min}$ in $\mathrm{G} 2$; in the pelvic members it occurred at $25 \pm 8.18 \mathrm{~min}$ in $\mathrm{G} 1$ and at $39 \pm 10.48 \mathrm{~min}$ in $\mathrm{G} 2$; and in the tail it was recorded at $40.50 \pm$ $10.12 \mathrm{~min}$ in $\mathrm{G} 1$ and at $42 \pm 11.86 \mathrm{~min}$ in $\mathrm{G} 2$.

Several side effects, such as tearing, emesis, sialorrhea, urination and defecation, were observed after the administration of neostigmine and associated with its side effects.

\section{Discussion}

P. expansa reaches sexual maturity starting from the age of five years ${ }^{5}$. Since the specimens of this study were up to three years old, the influence of sexual hormones on the effects of the agents employed in this study is discarded.

Several dosages of rocuronium have been tested on Terrapene carolina major, and $0.25 \mathrm{mg} / \mathrm{kg}$ IM to $0.50 \mathrm{mg} / \mathrm{kg} \mathrm{IM}$ have been suggested for procedures such as intubation ${ }^{7}$. These dosages were also used in this study of healthy $P$. expansa, showing a similar effect, with satisfactory levels of muscle relaxation and handling achieved in $10 \mathrm{~min}$.

Reptiles show variable induction and recovery times, but they tend to be longer than in mammals, due to their lower metabolism and their response to climate variations ${ }^{4}$. The experiment was carried out in a location where this species is native, and the ambient temperature and humidity in this study were constant and considered optimal for this research on $P$. expansa.

Air reaches the lungs of Testudines through a pumping mechanism carried out by striated skeletal muscles, which press the organs of the cavity to produce pressure ${ }^{4}$. That is why the respiration of turtles is affected directly when an NMB is used. The type of respiration observed in $P$. expansa - rapid movements followed by apnea - is considered normal for aquatic Testudines ${ }^{6}$, since they are also able to hold their breath at least ten times longer than other reptiles ${ }^{3}$. The changes in respiratory patterns were not a cause for concern, since no alterations such as cyanosis were observed, and recovery of the complete respiratory pattern soon occurred.

The bradycardia observed in three $P$. expansa was attributed to the use of neostigmine, which has muscarinic side effects $^{14}$, and not to rocuronium, since this drug exerts minimal action upon the cardiovascular system ${ }^{12}$. This finding was reinforced by the satisfactory response to the administration of atropine. Glicopirrolate-responsive bradycardia has been similarly reported in T. carolina major ${ }^{7}$.

The time of palpebral reflex loss with the use of rocuronium in $T$. carolina major occurred independently of the dosage, sex and ambient temperature ${ }^{7}$, contrary to what occurred with $P$. expansa, since significant differences were found at 5 and 30 min, when G1 lost and recovered the palpebral reflex earlier than did G2.

Loss of pupillary reflex occurred basically in G2, and can be explained by two hypotheses: excessively deep degree of neuromuscular blockage due to an excessive dosage, which would inactivate this reflex ${ }^{4}$, or a muscarinic side effect of neostigmine ${ }^{10,14}$.

Handling was directly affected by the dose, which is consistent with what was reported for T. carolina major ${ }^{7}$. G2 began score 3 at the same time as G1, in up to $10 \mathrm{~min}$, but remained at this score for longer, from 20 to $45 \mathrm{~min}$. However, the groups showed no statistically significant differences in muscle relaxation and locomotion in any of the measurements, unlike the abovementioned authors, who reported $\mathrm{p}>0.05$ in muscle tone and locomotion recovery time.

It has been reported ${ }^{9}$ that loss of the response to painful stimulus, which was recorded in all the specimens here, occurs not through the analgesic or hypnotic effect of rocuronium, but because of the animals' incapacity to respond due to the paralysis caused by the NMB.

The scope of this study was not to determine if neostigmine would reduce the recovery time, since there was no control group. This drug was used because the blocking effect of rocuronium is of intermediary duration ${ }^{12}$ and there was no intention to provide ventilatory support, since this was a field experiment.

The use of neostigmine produced side effects such as emesis, defecation, urination, sialorrhea and bradycardia, which could probably be prevented through the use of atropine or glicopirrolate a few minutes before administering neostigmine. The concomitant use of muscarinic antagonists such as atropine and glicopirrolate with anticholinesterase inhibitors such as neostigmine, in order to avoid muscarinic side effects, has already been suggested ${ }^{15}$. Despite these undesirable effects, the anticholinesterase inhibitor used here was considered safe and probably reduced residual muscle weakness, an interesting situation when one intends to use the NMB agent in specimens from natural environments.

Rocuronium in P. expansa showed dose-dependent effects and few side effects, similarly to what has been reported for domestic mammals ${ }^{9,1}$ and T. carolina major ${ }^{7}$. Likewise, it was found advantageous when compared with succinylcholine - which does not have an erratic action time of $45 \mathrm{~min}$ to 12 hours and is not reversible, and with gallamine - which has a recovery time of 7 to 9 hours ${ }^{4,8,11}$, since its duration was relatively short, all the animals having recovered completely in up to 3 hours.

\section{Conclusions}

Rocuronium in doses of 0.25 and $0.50 \mathrm{mg} / \mathrm{kg} \mathrm{IM} \mathrm{in}$ $P$. expansa is safe and affective as an aid in clinical and preanesthetic procedures, producing complete muscle relaxation, easy handling and loss of locomotion for dose-dependent periods. Since no statistical differences between the doses for most of the parameters, and G1 was as efficient as G2, the lower dosage is recommended.

When $0.07 \mathrm{mg} / \mathrm{kg}$ IM neostigmine is used after the administration of rocuronium in $P$. expansa, the previous application of atropine can be adopted as a standard procedure. 


\section{References}

1. Adams HR. Agentes bloqueadores neuromusculares. In: Adams HR. Farmacologia e terapêutica em veterinária. 8ed. Rio de Janeiro: Guanabara Koogan; 2003. p.114-26.

2. Almeida MCS. Uso de bloqueadores neuromusculares no Brasil. Rev Bras Anestesiol. 2004;54(6):850-64.

3. Belkin DA. Anaerobic brain function: effects of stagnat and anoxic anoxia on persistence of breathing in reptiles. Science. 1968;162(857):1017-8.

4. Bennett RA. A review of anesthesia and chemical restraint in reptiles. J Zoo Wildl Med. 1991;22(3):282-303.

5. Cantarelli VH. Alometria reprodutiva da tartaruga-da-Amazônia (Podocnemis expansa): bases biológicas para o manejo. [Tese Doutorado]. Universidade de São Paulo, Escola Superior de Agricultura Luiz de Queiroz; 2006.

6. Holz P, Holz RM. Evaluation of ketamine, ketamine/xylazine, and ketamine/midazolam anesthesia in red-eared sliders (Trachemys scripta elegans). J Zoo Wild 1 Med. 1994; 25(4):531-7.

7. Kaufman GE, Seymour RE, Bonner BB, Court MH, Zaras AZ. Use of rocuronium for endotracheal intubation of North American Gulf Coast box turtles. J Am Vet Med Assoc. 2003;222(8):1111-5.

8. Lloyd ML. Crocodilian anesthesia. In: Fowler ME, Miller RE. Zoo and wild animal medicine. Current Therapy 4. Philadelphia: WB Saunders Company; 1999. p.205-16.
9. Marsico Filho F, Nascimento PRL. Bloqueadores neuromusculares. In: Fantoni DT, Cortopassi SRG. Anestesia em cães e gatos. São Paulo: Roca; 2001. p.184-92.

10. Maruyuki I. Normastig (metilsulfato de neostigmina). Available from URL: http://www.uniaoquimica.com.br/Bulas/normastig.pdf.

11. Massone F. Contenção física e anestesia em animais silvestres. In: Massone F. Anestesiologia veterinária: farmacologia e técnicas. 4ed. Rio de Janeiro: Guanabara Koogan; 2003. p.209-15.

12. Morgan Jr GE, Mikail MS, Murray MJ. Neuromuscular blocking agents. In: Morgan Jr GE, Mikail MS, Murray MJ. Clinical anesthesiology. 4ed. New York: Lange Medical Books/ McGraw-Hill Medical Publishing Division; 2006. p.162-75.

13. Mundim AV, Queiroz RP, Santos ALQ, Belleti ME, Luz VLF. Bioquímica sanguínea da tartaruga da Amazônia (Podocnemis expansa) em seu habitat natural. Biosc J. 1999;15(2):35-43.

14. Tarver GJ, Simon JA, Grove KB, Bom A, Cooke A, Rutherford SJ, Zhang MQ. 2-O-Substituted cyclodextrins as reversal agents for the neuromuscular blocker rocuronium bromide. Bio Med Chem. 2002;10(6):1819-27.

15. Taylor P. Agentes que atuam na junção neuromuscular e nos gânglios autônomos. In: Hardman JG, Limbird, LE, Gilman AG. As bases farmacológicas da terapêuticas. 10ed. São Paulo: Mc Graw Hill Interamericana do Brasil; 2003. p.147-62.

Conflict of interest: none Financial source: none

\section{Correspondence:}

André Luiz Quagliatto Santos

Av. Amazonas, 2245,

38405-302 Uberlândia-MG Brazil

quagliatto@famev.ufu.br.

Received: January 14, 2009

Review: March 17, 2009

Accepted: April 14, 2009

\section{How to cite this article}

Bosso ACS, Santos ALQ, Brito FMM, Alves Jr JRF, Guimarães EC. The use of rocuronium in giant Amazon turtle Podocnemis expansa (Schweigger, 1812) (Testudines, Podocnemididae). Acta Cir Bras. [serial on the Internet] 2009 July-Aug;24(4).

Available from URL: http://www.scielo.br/acb 